\title{
Towards Improving South Africa's Legislation On Tax Evasion: A Comparison Of Legislation On Tax Evasion Of The USA, UK, Australia And South Africa
}

Ansia Storm, North-West University, South Africa

Karina Coetzee, North-West University, South Africa

\begin{abstract}
The fight against tax evasion in South Africa is an ongoing battle. The tools available to law enforcement boil down to legislation and the enforcement thereof. The purpose of the study that was done for this article was to compare available legislation of the United States of America, United Kingdom, Australia and South Africa to determine if South Africa's legislation can be improved. This was done by studying the relevant literature and legislation of all four countries. The findings, that there is some clauses that can be added to improve South Africa's legislation, were confirmed by analyzing the legislation available. In theory, the results have proven that although South Africa's legislation can compete with that of the United States of America, United Kingdom and Australia, there is some improvement that can be considered. This is of value to the individuals and professionals who deal with the offence of tax evasion on a daily basis, ensuring that the reviewed legislation will deter perpetrators or that the charges brought against them in the court of law will ensure harsher punishment.
\end{abstract}

Keywords: Tax Evasion; Comparison of Legislation on Tax Evasion; South Africa

\section{INTRODUCTION}

"The income tax created more criminals than any other act of government" (Monti).

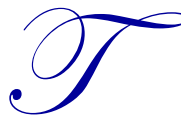

hese criminals do not only refer to tax evaders but also to those resisting taxes. According to an encyclopedia article, tax resistance can be defined as "the refusal to pay tax because of opposition to the government that is imposing the tax or to government policy as opposition to the concept of taxation itself. Tax resistance is a form of direct action and if in violation of the tax regulations, a form of civil disobedience." There are two techniques of tax resistance methods, namely legal and illegal. An example of a legal technique is tax avoidance while tax evasion is an example of one of the illegal techniques. (The Free Dictionary).

Kirchler (2007) stated that" it has been suggested that tax resistance might have played a huge role in the collapse of several empires, including the Egyptian, Roman, Spanish and Aztec" (p.182). The American Revolution, Great Revolt and the French Revolution were some of the historic events where tax uprisings began. Tax resistance can be traced back as far as the first century B.C. (Kirchler, 2007; Burg, 2004).

In the first century B.C in Judea, the Jewish extremists fought the poll tax established by the Roman Empire (Gross; 2008). According to Swartley (1980) in Luke 23:2, Jesus was accused of promoting tax resistance. The period before 1500 B.C includes historic events such as the Great Revolt, the first Jewish-Roman War; the "Norman anti-tax riots (1348 - 1351)" and "Wat Tyler's Rebellion (1381)". Recent tax resistance events in the $21^{\text {st }}$ century include the Tax protest and strike in Romania in 2010; the Nepalese doctor s who planned to engage in tax resistance in 2010 to protest the government and the organized resistance to paying the Mafia in 2006. (Burg, 2004). 
Little could be found on the history of tax evasion. "Unfortunately, there is no such history...no systematic investigation of tax evasion through the centuries." (As Maine Goes). According to Foreman (2015) tax evasion has been around since ancient Mesopotamia where Sumerians were known to have worked the black market. Evidence of this was found on a nineteenth century B.C Sumerian cuneiform tablet.

Emperor Nero of the Roman Empire ruled from 54 to 68 B.C. His predecessors utilized an excessive growth, minimal tax policy during their reign. Nero however, abandoned these policies and instead created a downward spiral of inflationary measures together with extreme taxation. Due to this, widespread tax evasion forced the economically strained Rome to practice expropriation by the third century. Emperors such as Diocletian, Constantine and Julian tried to restore fiscal order, but Rome collapsed in 476 A.D by which time great landowners outside the city had already turned against its authority and stopped paying taxes. (Adams, 2001; Foreman, 2015). From the information gathered, it appears that the collapse of the Roman Empire might have been caused by tax evasion (Adams, 2001).

Another example of an empire that fell due to tax evasion is that of the Ming Dynasty in China. According to O'Brien (2007) the Ming Dynasty was plagued by tax evasion to such an extent that it experienced financial difficulties. After trying to reform its tax system, which failed, the Dynasty ended in 1644.

The Qing Dynasty took over and had zero tolerance for tax evaders. The Qing Dynasty knew that tax evasion was responsible for government deficits during the Ming Dynasty's reign. Government's revenues rebounded due to the Qing Dynasty's harsh punishment for taxpayers evading or who abused the exemption system. By the late 1660's the tax payers were too beaten and cowed to risk not paying their taxes. (O'Brien, 2007; Thackeray, 2012; Foreman, 2015).

From the above information, it is apparent that tax evasion and harsh taxes were a major cause of the downfall of empires and dynasties throughout history. This is a very important fact (lesson) that governments need to consider in their pursuit of eradicating tax evasion. It is important to learn from the mistakes that previous governments made, and to be continually searching for a better solution. The problem of tax evasion as well as the importance thereof will be discussed in the following paragraphs to emphasize the need of the research done for this article.

\section{TAX EVASION: THE PROBLEM}

\section{The Importance of Taxes}

The Encyclopedia Britannica defines the purpose of taxation as primarily to raise revenue for government expenditure. A very good explanation of what taxation entails is "[taxation] is a system of compulsory contributions levied by government on persons, corporations, and properties, primarily as a source of revenue for government's expenses and other public purposes. It is for this reason, in order for the government to provide the public with the necessary goods and services; revenue must be raised through taxation" (Inland Revenue Division of Dominica). The Organization for Economic and Co-Operation Development (OECD) defines tax as a compulsory unrequited payment to the government (Messere \& Owens (n.d)). According to Venter, Stiglingh, Koekemoer, Oosthuizen and Cass (2015) the purpose of taxes is to enable Government to provide services to the people. These four definitions clarify the purpose of taxation as raising revenue for government expenditure.

The definition of tax evasion on which the rest of the article will be based has been established as the non-payment or underpayment of taxes. This presents a problem to any country's government who has to render services to its citizens but who do not have adequate funds (from tax collection) to do so. In the next part of this article, the international problem of tax evasion will be discussed.

\section{An International Problem}

\section{Tax Evasion}

In 2011 the Tax Justice Network (TJN) compiled a paper which used the following approach in order to calculate the best estimates on the cost of tax evasion: 
1. A country's estimate was done on the absolute size of the shadow economy based upon published estimates of that country's Gross Domestic Product (GDP) as well as recently-reported data on the size of shadow economies published by the World Bank. The shadow economy can be defined as "the part of an economy involving goods and services which are paid for in cash, and therefore not declared for tax" or illicit economic activity existing alongside a country's official economy (BusinessDictionary.Com; Oxford Dictionaries). The TJN's definition of the economic activity in a country's shadow economy refers to tax evading

2. Next they made an estimation of taxes lost as a consequence of the shadow economy by calculating the relation of average tax to GDP as well as the relation of average tax to the shadow economy of that country under review. To put the data into perspective, they compared the lost taxes to healthcare spending. For purposes of this paragraph however, there will be no referral to healthcare spending.

The TJN's research estimated total tax evasion of more than US\$3.1 trillion or 5.1\% of the global GDP can be attributed to the shadow economy. (The Tax Justice Network: 2011).

The following is an abstract from a table compiled by the TJN showing the top ten countries' loss to tax evasion.

Table 1. Tax Justice Network: Top 10 Countries' loss to Tax Evasion: 2011

\begin{tabular}{l|c|c|c|c|c}
\hline \multicolumn{1}{|c}{ Country } & GDP & $\begin{array}{c}\text { Tax burden } \\
\text { Overall }\end{array}$ & $\begin{array}{c}\text { Magnitude of } \\
\text { Shadow } \\
\text { Economy }\end{array}$ & $\begin{array}{c}\text { Magnitude of } \\
\text { Shadow } \\
\text { Economy }\end{array}$ & $\begin{array}{c}\text { Tax lost } \\
\text { attributed to } \\
\text { Shadow } \\
\text { Economy }\end{array}$ \\
\hline United States & US\$ 'm & \% & US\$ 'm & \% & US\$ 'm \\
\hline Brazil & 14582400 & 26.9 & 1254086 & 8.6 & 337349 \\
\hline Italy & 2087890 & 34.4 & 814277 & 39.0 & 280111 \\
\hline Russia & 2051412 & 43.1 & 553881 & 27.0 & 238723 \\
\hline Germany & 1479819 & 34.1 & 648161 & 43.8 & 221023 \\
\hline France & 3309669 & 40.6 & 529547 & 16.0 & 214996 \\
\hline Japan & 2560002 & 44.6 & 384000 & 15.0 & 171264 \\
\hline China & 5497813 & 28.3 & 604759 & 11.0 & 171147 \\
\hline United Kingdom & 5878629 & 18.0 & 746586 & 12.7 & 134385 \\
\hline Spain & 2246079 & 38.9 & 280760 & 12.5 & 109216 \\
\hline
\end{tabular}

The information in table one was obtained from the World Bank for the GDP, OECD and the Central Intelligence Agency. Australia ranked $19^{\text {th }}$ out of 145 countries with total tax lost as a result of the shadow economy of US\$39 879 million and South Africa ranked $26^{\text {th }}$ with a total tax loss of US\$25 518 million.

In order to estimate the tax lost as a result of the shadow economy for 2013, the same approach as that of the TJN's was followed. The information used was obtained from the following websites:

1. World Bank for the GDP

2. Schneider's (2013) "Size and Development of the Shadow Economies of Portugal and 35 other OECD Countries from 2003 to 2013: Some New Facts". For the size of the shadow economy in percentage.

3. The Central Intelligence Agency's The World Factbook for the percentage of the tax burden overall.

The size of the shadow economy (US\$) and the tax lost as a result of the shadow economy were calculated. Unfortunately, not all figures for South Africa were available. 
Table 2. Author's Estimated Tax Evasion: 2013

\begin{tabular}{|l|c|c|c|c|c|}
\hline \multirow{2}{*}{ Country } & $\begin{array}{c}\text { World Bank: } \\
\text { GDP }\end{array}$ & $\begin{array}{c}\text { Tax burden } \\
\text { Overall } \\
\text { (according to the } \\
\text { CIA) }\end{array}$ & $\begin{array}{c}\text { Magnitude of } \\
\text { Shadow } \\
\text { Economy }\end{array}$ & $\begin{array}{c}\text { Schneider: } \\
\text { Magnitude of } \\
\text { Shadow } \\
\text { Economy }\end{array}$ & $\begin{array}{c}\text { Tax lost } \\
\text { attributed to } \\
\text { Shadow } \\
\text { Economy }\end{array}$ \\
\hline United States & US\$ 'm & $\mathbf{\%}$ & US\$ 'm & \% & US\$ 'm \\
\hline United Kingdom & $16,770,000$ & 17.0 & $1,106,820$ & 6.6 & 188,159 \\
\hline Australia & $2,678,000$ & 41.1 & 259,766 & 9.7 & 106,764 \\
\hline South Africa & $1,560,000$ & 33.2 & 146,640 & 9.4 & 48,684 \\
\hline
\end{tabular}

\section{THE TAX JUSTICE NETWORK}

The Tax Justice Network Limited is a British registered company and a worldwide system established "in 2003 dedicated to high-level research, analysis and advocacy in the field of international tax as well as the international aspects of financial regulation". Amongst others, the Tax Justice Network explains the harmful impacts of tax evasion and "has been one of the most important players bringing tax justice to global attention since 2003". One of the Tax Justice Network's fundamental objectives is "to create understanding and to promote reform in poorer countries". Since the Tax Justice Network's establishment in 2003, they have grown globally to include allies such as Australia, the United States of America and Africa. (The Tax Justice Network).

The Global Alliance for Tax Justice seceded in 2013 from the Tax Justice Network and is a movement of civil society organizations and activists "united in campaigning for greater transparency, democratic oversight and redistribution of wealth in national and global tax systems." The reason for their beginning is the universal tax avoidance and tax evasion which are twisting economies and depriving people of the public services needed to live. This universal tax avoidance and tax evasion is caused by wealthy people, banks and multinational corporations who deliberately pay less and less tax on their profits, causing losses to ordinary individuals in terms of wealth flowing from society to a handful of particular individuals. (Global Alliance for Tax Justice).

According to the "Global Alliance for Tax Justice", there is a massive necessity for honest tax proceeds to help alter the increase of disparity, to fight impoverishment and to plough money into infrastructures. Their vision is to "create a world where fair and progressive tax policies support people to share in local and global prosperity" and to have access to the public services and community-based defences. Included in its goals are the following:

- To end secrecy and create more public accountability for companies;

- To develop or create or assist in the development of international tax rules that are fair for all countries;

- To bring about progressive, transparent and sufficiently resourced tax systems;

- To realise public investment in services and sustainable development.

They want to achieve this "by exposing the negative impact of tax injustices on ordinary people, taking transformative actions and campaigning for solutions to end tax injustices" and by "building a global movement to increase awareness and solidarity around tax justice issues". (Global Alliance for Tax Justice).

The Tax Justice Network created and is still active in exposing offshore tax evasion and tax avoidance, forcing governments to develop plans to combat this. With the help of the Global Alliance for Tax Justice which focuses primarily on fair tax revenues and improving the lives of all, this might make a difference in the fight against tax evasion on a global scale.

\section{THE ORGANIZATIOIN FOR ECONOMMIC CO-OPERATION AND DEVELOPMENT (OECD)}

Unlike the Tax Justice Network and Global Alliance for Tax Justice, the objective of the OECD is to assist governments to nurture wealth and fight poverty through economic growth and financial stability. 
The organization was created in 1960 by 18 European countries, the United States and Canada dedicated to global development. The membership of the OECD has since grown to include 34 countries across the globe. These countries include Australia, the United States and the United Kingdom. Although Africa (or South Africa) is not a member of the OECD, the OECD indicates that they are working closely together with Africa. (Organization for Economic Co-operation and Development).

The "Global Forum on Transparency and Exchange of Information for Tax Purposes" level on automatic trade of data was supported in 2014 by all OECD and G20 countries. The "Global Forum" is the largest global network for international collaboration with regards to tax and the trade of financial data. The" Standard for Automatic Exchange of Financial Account Information in Tax Matters" provides for the exchange of all financial information on an annual basis, automatically. The "Global Forum" also encouraged emergent nations to participate in the convergence of automatic trade of data. According to the OECD's newsroom, governments of African countries decided to introduce an "African Initiative" to raise attentiveness of the advantages of transparency in Africa. The fact that so many jurisdictions agreed to automatically exchange information led to the OECD Secretary-General Angel Gurria statement that there is tangible growth in the convergence of the G20 objective of successfully combat tax evasion. He further stated that "the world is quickly becoming a smaller place for tax cheats, and we are determined to ensure that developing countries also reap the benefits of greater financial sector transparency." (Organization for Economic and Co-operation Development).

\section{THE AVAILABLE LEGISLATION ON TAX EVASION IN THE UNITED STATES OF AMERICA, THE UNITED KINGDOM, AUSTRALIA AND SOUTH AFRICA}

The United States is the one country in the world that has taken the threat of organized crime seriously after the unfortunate events of September 11, 2001. The prevention of money laundering has been put very near the top of the US administration's agenda (Lilley, 2012). The United States is considered to be a first world country and is a leader in most fields, hence its selection of being one of the countries to be analyzed in order to answer the research questions. Australia is the second first world country chosen to analyze, due to their vigorous attempts (and successes) to control and measure money laundering (Lilley, 2012).

The United Kingdom was selected due to its rich history with South Africa, being a large international financial center (Banker's Academy) and according to the Corruption Perceptions Index for 2016; the United Kingdom scored 81 out of 100 and it ranks 10 out of 176 countries. From all four countries chosen, the United Kingdom ranks the highest, with Australia 13 out of 176, United States at 18 out of 176 and South Africa at 64 out of 176. (Corruption Perception's Index: 2016). This means that from all four countries, the United Kingdom is the "cleanest" when it comes to corruption.

South Africa was chosen as the third world country to analyze because, except for being number 64 on a list of 176 countries, there are daily reports in newspapers of corruption and the Financial Action Task Force states on its website that "Corruption and money laundering are intrinsically linked" (Corruption).

\section{The United States of America}

The "Internal Revenue Service" (IRS) is the United States of America's tax organization and administers the "Internal Revenue Code" enacted by Congress (About IRS). The history of the IRS can be traced back to 1862 when President Lincoln and Congress passed an income tax law to settle war expenditures. In 1872, the income tax was repealed only to be revived again in 1894 by Congress but in 1895 the Supreme Court ruled it unconstitutional.

In 1913, the sixteenth Amendment was ratified which resulted in Congress having the authority to enact an income tax. In the 1950's the agency's name was changed from 'The Bureau of Internal Revenue' to the 'Internal Revenue Services'. (Brief History of IRS).

Tax investigations can be divided into two divisions within the IRS: civil fraud or criminal fraud. They have two departments who deal with these investigations. The department who investigates civil fraud is called the Civil Division and the other department who investigates criminal fraud is called the Criminal Investigation Division. 
(Odom: 2015; IRS: Criminal Investigation at a glance). Sometimes the Criminal Division works with the Federal Bureau of Investigation (FBI) to investigate potential tax evasion.

In Title 26 of the Internal Revenue Code, chapter 75 deals with crimes, other offences and forfeitures which are written up under sections 7201 to section 7217. Section 7201 deals with "Attempt to evade or defeat tax". Section 7201 states: "Any person who willfully attempts in any manner to evade or defeat any tax imposed by this title or the payment thereof shall, in addition to other penalties provided by law, be guilty of a felony and, upon conviction thereof, shall be fined not more than $\$ 100000$ (\$500 000 in the case of a corporation), or imprisoned not more than 5 years, or both, together with the costs of prosecution." (The Internal Revenue Code). This is also called the tax evasion statute (Odom: 2015). The definition of a felony is a major crime with a minimum penalty of one year in prison (Your dictionary).

Another code under which a person or a business can be criminally prosecuted is Title 18 of the "United States Code". Title 18 deals specifically with "crimes and criminal procedure". Under Part 1 of Chapter 19 of Title 18, section 371 deals with plots to commit offenses or to deceive the United States. This section states: "If two or more persons conspire either to commit any offense against the United States, or to defraud the United States, or any agency thereof in any manner or for any purpose, and one or more of such persons do any act to affect the object of the conspiracy, each shall be fined under this title or imprisoned not more than 5 years, or both." (United States Code: Title 18).

The "Internal Revenue Code" (Title 26 USC) and Title 18 of the "United States Code" contains several illegal fines relevant to tax cases; yet, according to Odom (2015) "almost all criminal tax investigations and prosecutions concern five statutes, four felonies and one misdemeanor". (Odom, 2015). A summary of these five statutes will be given.

1. 26 USC 7201: "Attempt to evade or defeat tax".

This section of the "Internal Revenue Code" has already been mentioned earlier. According to the Supreme Court, section 7201 contains two types of evasion namely, "the willful attempt to evade or defeat the assessment of tax" and "the willful attempt to evade or defeat the payment of tax". This was established in a court case Sansone v, US, 380US 343, 354 (1965).

The elements of the offence can be broken down as:

a. an effort to avoid tax or the payment thereof; and

b. willfulness.

Willfulness is defined as the "voluntary, intentional violation of a known legal duty" (US v. Pomponio, 429 US 10, 12 (1976)).

2. 26 USC 7206(1): "Fraud and False Statement".

According to this section it is a crime for a person to sign a tax return knowing that it is false or that there is a material misstatement in this return. 26 USC 7206(2): "Assisting in the preparation of a false return".

In "US v Williams, 644 F. 2d 696, 701 ( $8^{\text {th }}$ Cir. 1981)" the court described this section as the "aiding and abetting" section of the Internal Revenue Code. Most often the tax preparers are the targets under this section of the law.

3. 26 USC 7203: "Failure to file, supply information or pay tax".

Four distinct offences can be identified under this statute, namely "failure to pay an estimated tax or tax; failure to file a return; failure to keep records and failure to supply information". 
4. 18 USC 371: "Conspiracy to defraud the United States".

Due to the fact that the Internal Revenue Code does not include a statue that deals with conspiracy, government indicts tax-related plots under 18 USC 371. According to thisstatute, there are two categories of plots, namely" a conspiracy to commit any federal offense and a conspiracy to defraud the United States" (also called the Klein conspiracy).

(Odom, 2015)

The following tax statistics was published in 2016 on the website of the IRS (SOI - Tax Stats):

Table 3. Internal Revenue Service: Tax Statistics

\begin{tabular}{|c|c|c|c|c|c|c|}
\hline Year & $\begin{array}{c}\text { Investigations } \\
\text { Completed }\end{array}$ & $\begin{array}{c}\text { Referrals for } \\
\text { prosecution }\end{array}$ & $\begin{array}{c}\text { Indictments } \\
\text { and } \\
\text { information }\end{array}$ & $\begin{array}{c}\text { \% indictments } \\
\text { and } \\
\text { information }\end{array}$ & Convictions & \% convictions \\
\hline $\mathbf{2 0 1 4}$ & 4606 & 3478 & 3272 & 94 & 3110 & 89 \\
\hline $\mathbf{2 0 1 3}$ & 5557 & 4364 & 3865 & 89 & 3311 & 76 \\
\hline $\mathbf{2 0 1 2}$ & 4937 & 3701 & 3390 & 92 & 2634 & 71 \\
\hline $\mathbf{2 0 1 1}$ & 4697 & 3410 & 2998 & 88 & 2350 & 69 \\
\hline $\mathbf{2 0 1 0}$ & 3415 & 3034 & 2645 & 87 & 2184 & 72 \\
\hline
\end{tabular}

Indictments and information refer to accusations of criminal charges. Indictments are accusations made by a Federal prosecutor and issued by a Federal grand jury while information is accusations made by a Federal prosecutor that does not require a grand jury.

The percentage indictments and information were calculated using the following formula:

$$
\mathrm{Y} 1=(\mathrm{A} 1 \div \mathrm{B}) \times 100
$$

Where $\mathrm{Y} 1=\%$

$\mathrm{A} 1=$ total indictments and information for a specific year

$\mathrm{B}=$ referrals for prosecutions for that specific year

The percentage convictions were calculated using a similar formula:

$$
\mathrm{Y} 2=(\mathrm{A} 2 \div \mathrm{B}) \mathrm{x} 100
$$

Where $\mathrm{Y} 2=\%$

$$
\begin{aligned}
& \mathrm{A} 2=\text { total convictions for a specific year } \\
& \mathrm{B}=\text { referrals for prosecutions for that specific year }
\end{aligned}
$$

The average successful indictment and information rate over a five year period was $90 \%$ while the average successful conviction rate over the same five year period was $75 \%$.

Another piece of legislation that was developed in the fight against tax evasion was the "Foreign Account Tax Compliance Act". The "Foreign Account Tax Compliance Act (FATCA)" was passed as law during March 2010 and entered into effect on 1 January 2013 (IRS: Foreign Account Tax Compliance Act; CITCO). The purpose of this legislation "is to target tax non-compliance by United States taxpayers with foreign accounts"; the objective is the reporting of foreign financial assets. (IRS: Foreign Account Tax Compliance Act). According to CITCO (2011) "FATCA will require foreign financial institutions to enter into an agreement with the IRS under which the foreign financial institution is obligated to report directly to the IRS, certain information about financial accounts and investments held by US individuals or by foreign entities in which an US individual holds an ownership interest". If 
institutions fail to comply, FATCA requires a withholding tax of $30 \%$ on certain income and gross proceeds payments made to them (BlackRock, 2011). There is no mention of any criminal or civil prosecution for a non-compliant institution.

\section{The United Kingdom}

"Her Majesty's Customs and Revenue" (HRMC) and the "National Crime Agency" (NCA) investigate alleged tax fraud. The Taxes Management Act of 1970 which deals with fraudulent evasion of income tax is only one of many acts in the UK that deals with tax fraud. Other examples are the Value Added Tax Act 1994 and the Customs and Excise Management Act 1979. (HM Revenue and Customs). As a limitation of scope, only income tax will be focused on.

The primary tax scheme felonies in the UK are the "fraudulent evasion of income tax, fraudulent evasion of VAT, cheating the public revenue, providing false documents or information to HMRC and fraudulent evasion of excise duty on imported goods or smuggling goods". The popular tax felonies are created by statute except for the offence of cheating the public revenue. This is a common law offence and is dealt with under the Theft Act 1968. (Tax evasion offences).

Section 106A of the Taxes Management Act 1970 states:

1) "A person commits an offence if that person is knowingly concerned in the fraudulent evasion of income tax by that or any other person.

2) A person guilty of an offence under this section is liable

a. on summary conviction, to imprisonment for a term not exceeding 12 months or a fine not exceeding statutory minimum, or both, or

b. on conviction on indictment, to imprisonment for a term not exceeding seven years or a fine, or both.

3) In the application of subsection (2)(a) -

a. In England and Wales in relation to offences committed before the commencement of section 282(3)

of the Criminal Justice Act 2003; and

b. In Northern Ireland, for " 12 months".

4) This section does not apply to things done or omitted before $1^{\text {st }}$ January 2001 ".

(The Taxes Management Act 1970)

The definition of 'knowingly concerned' is a person had knowledge of the fraud and was involved in the fraud. The behaviour must also be of a deceitful nature. This dishonesty is measured by the ethics of an ordinary individual where a perpetrator comprehended that his behavior was deceitful. (Tax evasion offences).

As already mentioned in section 106A of the Taxes Management Act 1970, the "maximum sentence on conviction is imprisonment not exceeding seven years or a fine, or both. On summary conviction the maximum penalty is six months imprisonment or a fine not exceeding £5 000". From 12 March 2015, there is no upper limit to the fine which the magistrates can impose for offences committed in England and Wales (Ministry of Justice, 2015).

Offences can be divided into three categories according to the British criminal justice system. These categories are: summary, either way or indictable. A summary offence is dealt with only in the magistrate's court because these offences are usually minor offences (Duhaime's Law Dictionary) for example assault (Criminal Justice Act 1988, s39). The either way offence is the more serious offences for example theft (Theft Act 1968: s1). An indictable offence is the most serious crimes for example, murder. (Law Teacher).

In the case of “Attorney General's References No. 86 and 87 of 1999”, the provoking features of tax (and excise) evasion for condemning purposes were recognized. It included:

a. "The sophisticated nature of the fraud;

b. The exploitation of a scheme; 
c. The breach of trust;

d. The fraudulent obtaining of money pursuant to the scheme coupled with suppression of profits;

e. The amount of loss to the Revenue;

f. The personal benefit; and

g. The concealment of the fraudulent nature of the claims at audit".

In the Thornhill [1980] the court case it was stated that: "Defrauding the Inland Revenue is a serious offence because it means defrauding the vast body of honest tax payers." The court further stated that an immediate verdict of incarceration may be the consequence of acknowledging guilt or by being found guilty. In another case, Alibhai [1992] the perpetrator was sentenced to seven years in prison after the court found it to be appropriate while in the case of Azziz [1996] a sentence of four and a half years were handed down during judgment. These judgments are an illustration of section 106A of the Taxes Management Act, 1970. (Prosecuting Tax Evasion, 2013).

The responsibility of the "Crown Prosecution Service" (CPS) is to indict tax based fraud however, the HMRC's policy deals with fraud by utilizing the "Civil Investigation of Fraud "(CIF) measures because it tends to cost less than criminal trials. Criminal prosecutions are usually set aside for the utmost severe cases. Examples of the circumstances where a criminal prosecution may be initiated are written in the policy of the HMRC. These examples include the following:

a) "In cases of organized crime gangs attacking the tax system;

b) Where materially false statements are provided in the course of a civil investigation;

c) Where deliberate concealment, deception, conspiracy or corruption is suspected".

The following statistics with regards to tax fraud prosecutions were published by HM Revenue and Customs (2014):

Table 4. UK: Tax Statistics

\begin{tabular}{c|c|c|c|c}
\hline Year & Prosecutions & \% rise in prosecutions & Convictions & \% convictions \\
\hline $\mathbf{2 0 1 0} / \mathbf{1 1}$ & 420 & - & 336 & $80 \%$ \\
\hline $\mathbf{2 0 1 1} / \mathbf{1 2}$ & 545 & $29.7 \%$ & 413 & $76 \%$ \\
\hline $\mathbf{2 0 1 2} / \mathbf{1 3}$ & 770 & $41.2 \%$ & 540 & $70 \%$ \\
\hline $\mathbf{2 0 1 3} / \mathbf{1 4}$ & 915 & $18.8 \%$ & 716 & $78 \%$ \\
\hline
\end{tabular}

There has been a rise in the total prosecutions since 2010 of $117.85 \%$ and $113.09 \%$ rise in the total convictions on tax evasion. The collective total of 2700 years of custodial sentences was handed down since April 2010 up until March 2014. (HRMC fast facts: 2014). The HRMC's target for 2014/2015 was set at 1165 prosecutions. It is unclear if they have reached their target as no information is yet available. (HMIC, 2013).

\section{Australia}

The Australian Taxation Office (ATO) is the main agency of the Australian Government for collecting revenue. They also work with other government agencies to combat tax evasion. The ATO refers to tax crime which includes the act of tax evasion. Their definition of a tax crime is "the abuse of tax and superannuation systems through intentional and dishonest behavior with the aim of obtaining financial benefit" (Tax Crime Explained). A superannuation system can be explained as the monthly payment made to someone who is retired from work (Thesaurus). According to the ATO convictions can take place as follows:

a) Serious tax crimes: prosecution by the Commonwealth Director of Public Prosecutions. The criminal convictions are recorded and in addition to this, the court can enforce "security bonds, community service orders, fines, additional penalties and prison sentences".

b) Summary offences: prosecuted by the ATO under the "Tax Administration Act 1953". If it is decided not to follow through with prosecution, administrative fines for failing to meet tax responsibilities can be enforced.

(The Australian Tax Office) 
Part three, division three of the Tax Administration Act contains all sections with regard to the prosecution of tax offences. Section 8ZA which specifically deals with the prosecution of tax offences, states:

(1) A taxation offence that is punishable by imprisonment for a period of 12 months is, when committed by a natural person, an indictable offence.

(2) A taxation offence that is punishable by imprisonment for a period not exceeding 12 months is, when committed by a natural person, punishable on summary conviction.

(3) A prescribed tax offence, when committed by a natural person is punishable by on summary offence.

(4) A taxation offence, when committed by a corporation is punishable on summary conviction.

(5) In spite of anything in the preceding provisions of this section, if:

(a) a person is convicted of two or more offences against section $8 \mathrm{~T}$ (incorrectly keeping records with intention of deceiving or misleading) or $8 \mathrm{U}$ (Falsifying or concealing identity with intention of deceiving or misleading)or both, before the same court at the same sitting; and

(b) assuming that the person had only been convicted of one of those offences, that offence would have been punishable on summary conviction;

All those offences are punishable on summary convictions.

(6) A reference in subsection (5) to a conviction of a person for an offence includes a reference to the making of an order under section 19B of the Crimes Act 1914 in relation to the person in respect of the offence.

(7) A reference in subsection (5) to an offence against section 8T or $8 \mathrm{U}$ includes a reference to an offence against section 11.1 of the Criminal Code that relates to an offence against section $8 \mathrm{~T}$ or $8 \mathrm{U}$, as the case may be.

(Tax Administration Act 1953)

The Taxation Administration Act refers to the application of the Criminal Code in section 2A. According to this section, chapter two of the Criminal Code Act 1995 sets out the general principals of criminal responsibility and applies to all offences against the Taxation Administration Act. (Commonwealth Consolidated Acts).

However, the main offences used to prosecute tax evasion are found in sections 134.1(1), 134.2(2) and 135.4(3) of the Criminal Code 1995. These sections being:

a) 134.1(1): dishonestly obtaining Commonwealth property;

b) 134.2(1): obtain financial advantage by deception;

c) 135.4(3): dishonestly cause a loss to the Commonwealth.

The penalty for the offences against the above-mentioned sections of the Criminal Code is ten years imprisonment. The prosecution of tax fraud is done by the Commonwealth Director of Public Prosecutions (CDPP) which was referred to them by the Serious Non-compliance area of the Australian Tax Office, the Australian Federal Police and the Australian Crime Commission. (Tax Fraud).

The Australian Tax Office tax crime prosecutions results are as follows:

Table 5. Australia: Serious Tax Crime Offences (Tax Crime Prosecution Results)

\begin{tabular}{c|c|c|c|c|c|c|c|}
\hline Year & Cases & Convictions & $\begin{array}{c}\text { \% convictions } \\
\text { of total cases }\end{array}$ & $\begin{array}{c}\text { Custodial } \\
\text { sentences }\end{array}$ & $\begin{array}{c}\text { Reparation } \\
\text { orders (\$\$m) }\end{array}$ & $\begin{array}{c}\text { Court fines } \\
\text { (\$) }\end{array}$ \\
\hline $\mathbf{2 0 1 4} / \mathbf{1 5}$ & 37 & 33 & 89 & 30 & 9.94 & 4,600 \\
\hline $\mathbf{2 0 1 3} / \mathbf{1 4}$ & 45 & 34 & 76 & 26 & 3.36 & 3,800 \\
\hline $\mathbf{2 0 1 2} / \mathbf{1 3}$ & 52 & 52 & 100 & 38 & 3.50 & 26,000 \\
\hline $\mathbf{2 0 1 1 / 1 2}$ & 39 & 39 & 100 & 37 & 4.80 & 10,500 \\
\hline $\mathbf{2 0 1 0} / \mathbf{1 1}$ & 62 & 60 & 97 & 53 & 17.00 & 7,500 \\
\hline
\end{tabular}

Over a five year period, the Commonwealth Director of Public Prosecutions had an average successful conviction rate of $92.40 \%$ for serious tax crimes. 
Table 6. Australia: Summary Prosecutions (Tax Crime Prosecution Results)

\begin{tabular}{c|c|c|c|c|c}
\hline Year & Cases & Convictions & \% of total Cases & $\begin{array}{c}\text { Dismissals and } \\
\text { withdrawals }\end{array}$ & $\begin{array}{c}\text { Fines } \\
\text { (\$m) }\end{array}$ \\
\hline $\mathbf{2 0 1 4}-\mathbf{2 0 1 5}$ & 1614 & 1540 & 95 & 74 & 9.59 \\
\hline $\mathbf{2 0 1 3}-\mathbf{2 0 1 4}$ & 1773 & 1540 & 87 & 233 & 13.02 \\
\hline $\mathbf{2 0 1 2}-\mathbf{2 0 1 3}$ & 1944 & 1691 & 87 & 253 & 7.38 \\
\hline $\mathbf{2 0 1 1}-\mathbf{2 0 1 2}$ & 2146 & 1961 & 91 & 185 & 7.41 \\
\hline $\mathbf{2 0 1 0}-\mathbf{2 0 1 1}$ & 1747 & 1518 & 87 & 229 & 7.51 \\
\hline
\end{tabular}

Over a five year period, the ATO had an average successful conviction rate of $89.40 \%$.

\section{South Africa}

Baragwanath J stated in Miller v CIR and McDougall v CIR that in the end avoidance and evasion is to be decided by the Commissioner, the Tax Review Authority and ultimately the court (Kumarasingam, 2010). The South African Revenue Service (SARS) is the tax collecting authority in South Africa which was established as an autonomous agency under the South African Revenue Service Act 34 of 1997 (the SARS Act).

Their main responsibilities are:

- To collect and administer all national taxes, duties and levies;

- To collect revenue that may be imposed under any other legislation as agreed on between SARS and a state entity entitled to the revenue;

- To provide a customs service that facilitates trade, maximizes revenue collection and protects South Africa's borders from illegal importation and exportation of goods; and

- To advise the Minister of Finance on all revenue matters.

This SARS Act mandates SARS to collect all revenues that are due; to ensure maximum compliance with relevant legislation; and to provide a customs service that will maximize revenue, facilitate trade and protect ports of entry against smuggling and other illegal trade. (Taxation in South Africa, 2014/2015).

The South African Revenue Service does not define tax evasion but their website explains what this autonomous body sees as tax crime. The examples mentioned are the following:

- People don't declare income in order to not pay the tax on that income.

- People lie about their expenses to reduce the tax they pay. For example they may lie about their business mileage, business expenses or even medical contributions.

- People simply don’t submit a tax return to SARS or fail to truthfully respond to our questions.

- Employers sometimes deduct tax from employees and never pay it over to SARS.

- Businesses sometimes charge VAT and never pay it over to SARS.

(What is tax crime?)

Comparing the above-mentioned examples to the definition of tax evasion, it is clear that it corresponds with the definition and it is thus safe to say that the term 'tax crimes' also includes the act of tax evasion.

The South African Revenue Service works together with other government agencies when enforcing tax laws. SARS not only enforce tax laws but also plays a role in administering other laws not related to tax but are vital to protect the South African economy against money laundering and corruption for example. They are active participants in the Multi-Agency Working Group and the Anti-Corruption Task Team charged with combating corruption in government. Laws such as the Financial Intelligence Centre Act (FICA), the Prevention of Organized Crime Act (POCA) and the Prevention and Treatment of Drug Abuse Act also lead SARS to join forces with the South African Police Department and the Financial Intelligence Centre. (SARS and the Criminal Justice System). 
The primary legislation administered by SARS includes amongst others the Income Tax Act 1962 as well as the Tax Administration Act 2011. The Income Tax Act contains the impermissible tax avoidance arrangements in section $80 \mathrm{~A}$ to $80 \mathrm{~L}$. Since tax avoidance is defined as arranging one's tax affairs in a legal manner as to reduce income to pay minimal tax or no tax at all, these sections will not be discussed.

The Tax Administration Act however, contains section 234 and 235 which levies penalties where non-compliance with tax acts and tax evasion have occurred. Section 234 deals with criminal offences relating to non-compliance with tax acts while section 235 deals with tax evasion and obtaining undue refunds by fraud or theft. For purposes of this chapter, only section 235 will be discussed due to its direct link to this chapter's subject.

Section 235 states that:

(1) A person who with intent to evade or to assist another person to evade tax or to obtain an undue refund under a tax Act -

(a) makes or causes or allows to be made any false statement or entry in a return or other document, or signs a statement, return or other document so submitted without reasonable grounds for believing the same to be true;

(b) gives a false answer, whether orally or in writing to a request for information under this Act;

(c) prepares, maintains or authorizes the preparation or maintenance of false books of account or other records or falsifies or authorizes the falsification of books or account or other records;

(d) makes use of, or authorizes the use of, fraud or contrivance; or

(e) makes any false statement for the purposes of obtaining any refund of or exemption from tax,

Is guilty of an offence and, upon conviction, is subject to a fine or to imprisonment for a period not exceeding five years. According to subsection (3) of section 235, a high-ranking SARS executive can inform the "South African Police Department" or the "National Prosecuting Authority". (Tax Administration Act No 28 of 2011).

The Prevention of Organized Crime Act (POCA) deals in chapter three with offences relating to proceeds of unlawful activities. The definition of unlawful activities according to POCA is "any conduct which constitutes a crime or which contravenes any law whether such conduct occurred before or after the commencement of this Act and whether such conduct occurred in the Republic or elsewhere..." This definition is wide enough to include the act of tax evasion because tax evasion is the contravention of the Tax Administration Act 2011.

In section five of chapter three POCA refers to assisting another to benefit from proceeds of unlawful activities which reads as follows:

"Any person who knows or ought reasonably to have known that another person has obtained the proceeds of unlawful activities, and who enters into any agreement with anyone or engages in any arrangement or transaction whereby-

(a) the retention or the control by or on behalf of the said other person of the proceeds of unlawful activities is facilitated; or

(b) the said proceeds of unlawful activities are used to make funds available to the said other person or to acquire property on his or her behalf or to benefit him or her in any other way, shall be guilty of an offence."

Section eight of chapter three states that "any person found guilty of an offence as contemplated in section four, five or six shall be liable to a fine not exceeding R100 million or imprisonment of a period not exceeding 30 years."

(Prevention of Organized Crime Act).

There are many information sites available about the crime rates and the convictions thereof for South Africa. Unfortunately, statistical information on the prosecution and conviction rates of tax evasion or tax crimes in South Africa could not be found. 
Here is a summary of statistical data that were found on the topic:

SARS declared in June 2015 that it achieved a 92\% conviction rate in tax and customs fraud cases for the 2015 financial year. There were 256 individuals and entities involved with a further 30 cases approved for criminal prosecution. The results of these convictions were an effective 555 years imprisonment, 258 months of correctional services, 2480 hours of community services and fines totaling R9 600 000. (SARS, 2015).

\section{Summary}

An analysis of the available legislation on the evasion of taxes in the United States of America, the United Kingdom, Australia and South Africa has been done in order to identify key points that could be considered for incorporation in the South African legislation. It was established in all four countries that the Tax Revenue bodies work with law enforcement to combat tax evasion. It was also established that all four countries regard the act of tax evasion as a serious unlawful act. However, it appears that the United States of America and Australia is the only countries (within this context) that views tax evasion as a crime against its government. The following table is a summary of the legislation involved in all four countries, the components of "tax evasion" and the penalties involved.

Table 7. Summary of Legislation by the author

\begin{tabular}{|c|c|c|c|c|}
\hline & USA & UK & Australia & SA \\
\hline Acts involved & $\begin{array}{l}\text { - Internal Revenue } \\
\text { Code } \\
\text { - United States Code } \\
\text { - FATCA }\end{array}$ & $\begin{array}{l}\text { - Taxes Management } \\
\text { Act } 1970 \\
\text { - Theft Act } 1968\end{array}$ & $\begin{array}{l}\text { - Tax Administration } \\
\text { Act } 1953 \\
\text { - Criminal Code Act } \\
1995 .\end{array}$ & $\begin{array}{l}\text { - Income Tax Act } 1962 \\
\text { - Prevention of } \\
\text { Organized Crime Act } \\
\text { - Tax Administration } \\
\text { Act }\end{array}$ \\
\hline $\begin{array}{l}\text { Components of tax } \\
\text { evasion or tax crime: }\end{array}$ & $\begin{array}{l}\text {-Willful attempt } \\
\text { - to evade or defeat }\end{array}$ & $\begin{array}{l}\text { - Knowingly } \\
\text { concerned; } \\
\text { - fraudulent evasion }\end{array}$ & $\begin{array}{l}\text { - ATO refers to tax } \\
\text { crimes which } \\
\text { includes tax evasion. } \\
\text { Components: } \\
\text { - abuse of tax systems, } \\
\text { - intentional, dishonest } \\
\text { behavior, } \\
\text { - aim to obtain } \\
\text { financial benefit. }\end{array}$ & $\begin{array}{l}\text { - Intentional, dishonest } \\
\text { behavior }\end{array}$ \\
\hline Penalties & $\begin{array}{l}\text { - An amount not } \\
\text { exceeding } \$ 100000 \text {, } \\
\text { or } \\
\text { - A prison sentence } \\
\text { not exceeding five } \\
\text { years, } \\
\text { - Or both } \\
\text { - Together with } \\
\text { paying the expenses } \\
\text { of prosecution }\end{array}$ & $\begin{array}{l}\text { Depends on type of } \\
\text { verdict. } \\
\text { - Summary } \\
\text { conviction: not more } \\
\text { than } 12 \text { months in } \\
\text { prison, or a fine, or } \\
\text { both. The fine does } \\
\text { not exceed } £ 5000 \text {. } \\
\text { From } 12 / 03 / 2015 \text { no } \\
\text { upper limit for } \\
\text { England or Wales. } \\
\text { - When convicted on } \\
\text { prosecution: } \\
\text { imprisonment of not } \\
\text { more than seven } \\
\text { years, or a penalty, or } \\
\text { both. }\end{array}$ & $\begin{array}{l}\text { Depends on type of } \\
\text { verdict. } \\
\text { Serious tax crimes: } \\
\text { criminal prosecutions } \\
\text { are recorded. } \\
\text { "Security bonds, } \\
\text { community service } \\
\text { orders, fines, } \\
\text { additional penalties } \\
\text { and prison } \\
\text { sentences" could be } \\
\text { imposed by court. } \\
\text { Summary offences: } \\
\text { administrative } \\
\text { penalties. }\end{array}$ & $\begin{array}{l}\text { Depends on type of } \\
\text { conviction. } \\
\text { TAA refers to a } \\
\text { penalty or } \\
\text { imprisonment not } \\
\text { exceeding five years. } \\
\text { POCA refers to } \\
\text { penalties not higher } \\
\text { than R100 million or } \\
\text { incarceration of not } \\
\text { more than } 30 \text { years. }\end{array}$ \\
\hline
\end{tabular}




\section{KEY POINTS TO CONSIDER FOR SOUTH AFRICAN LEGISLATION}

From the summary made in Table 7, it is evident that all four countries have the same understanding when it comes to the act of tax evasion. The levels of how serious it is taken by these countries' authorities are unclear. The Australian Tax Office states very clearly that "We take all forms of tax crime seriously" (Tax Crimes Explained). The fact that Australia and the United States of America views tax evasion as a crime against its government as well as their high conviction rates also indicates how serious they are to combat tax evasion.

The key points for South Africa to consider are:

a) Adopting the "crimes against the state" in the Tax Administration Act or in the Prevention of Organized Crime Act.

b) Implementing a more vigorous attitude towards prosecuting tax evaders. This may lead to appointing additional investigators and prosecutors in the South African Revenue Service or the National Prosecuting Authority of South Africa with the necessary knowledge and skills to achieve a successful conviction in terms of tax evasion or tax fraud.

c) Flowing from point $b$ ) above, increasing the appointment requirements for new employees. Depending on the department where the appointment will be made, a minimum of a bachelor's degree from an accredited tertiary institution applicable to the job description.

d) An intern specialist program to keep all employees up to date.

e) For the employees working in the investigation's department: special training in forensic accountancy and forensic techniques to increase their ability to detect and deter.

\section{CONCLUSION}

The main aim of this research was to identify and analyze applicable legislation of the United States, the United Kingdom, Australia and South Africa towards improving South Africa's legislation used to combat tax evasion. Appropriate literature, legal definitions, applicable legislation, reports published by applicable organizations and scholarly articles were studied. The solution to the research question can best be described by the analysis of the legislation of all four countries.

The findings in the analysis of the legislation lead to the identification of five key points in total. One key point can be considered by the South African Legislature for inclusion in the Prevention of Organized Crime Act or the Tax Administration Act. Four of these key points can be laid before the Commissioner of the South African Revenue Service for consideration. However, for these key points to be validated, one must refer back to Title 18 of the United States Code 371 as well as section 135.4(3) of Australia's Criminal Code 1995 where both express that it is a crime against the State.

The recommendation derived from the research is that the South African Legislature should consider adding "...crime against the Republic..." in the Prevention of Organized Crime Act or in the Tax Administration Act together with suitable penalties.

The contribution of this research is towards improving South Africa's legislation used to combat tax evasion. The key points identified can be corroborated by the proof found in this study. However, should the Legislature add these key points to one of the Acts mentioned above, the extent and success thereof in terms of prosecutions will only be measurable in a minimum of five years' time.

\section{AUTHOR BIOGRAPHIES}

Ansia Storm graduated from the North-West University in 2003 where after she continued her postgrad studies. She received her Master's degree in South African and International Taxation in 2005 and her Master's degree in Forensic Accountancy in 2009. She completed her articles and became a member of The South African Institute of Professional Accountants in 2006. She is currently busy with her PhD in Taxation and Forensic Accounting. After working as an 
accountant in practice for six years, she became a senior lecturer at the North-west University in Potchefstroom teaching mainly taxation and accounting.

Karina Coetzee completed a Masters and a D. Compt degree at UNISA. She is currently a professor in taxation at the Northwest University, a member of the South African Institute of Chartered Accounts and of the South African Institute of Tax Practitioners. Conference papers include various local and international papers, mainly relating to horizontal and vertical equity.

\section{REFERENCES}

About IRS. Retrieved from: https://www.irs.gov/uac/about-irs

Adams, C. (2001). For good and evil: The impact of taxes on the course of civilization. Madison Books. Retrieved from: https://books.google.co.za/books?id=YKMhQYfkJ5UC\&pg=PA75\&lpg=PA75\&dq=history+of +tax+evasion+rome\&s ource $=$ bl\&ots $=$ OI2J_5M5cS\&sig=6v5rC-

4jWrvrQcTqW7TfgRKL9NA\&hl=en\&sa=X\&ved=0ahUKEwj42u2X7rrLAhXGnBoKHVuXD6EQ6AEIQzAI\#v=onep age $\& \mathrm{q}=$ history $\% 20 \mathrm{of} \% 20$ tax $\% 20$ evasion $\% 20$ rome $\& \mathrm{f}=$ false

As Maine Goes: A history of tax evasion. (2012). Retrieved from: http://www.asmainegoes.com/content/history-of-tax-evasion

Attorney General's References No.'s 86 and 87 of 1999 [2001] 1 Cr App R (s) 141.

Australia. (1953). Tax Administration Act. Common Wealth Consolidated Acts. Retrieved from: http://www.austlii.edu.au/au/legis/cth/consol_act/taa1953269/

Banker's Academy. Anti-Money Laundering (AML) in United Kingdom. Retrieved from : http://bankersacademy.com/resources/free-tutorials/57-ba-free-tutorials/607-aml-uk-sp-635

BlackRock. (2011). Foreign Account Tax Compliance Act: Challenges for investors. Retrieved from: http://www.blackrock.com/corporate/en-za/literature/whitepaper/viewpoint-foreign-account-tax-compliance-act-may2011.pdf

Brief History of IRS. Retrieved from: https://www.irs.gov/uac/brief-history-of-irs

Burg, D.F. (2004). A world history of tax rebellions: An encyclopedia of tax rebels, revolts, and riots from antiquity to the present. Routledge.

Business Dictionary. Definition of shadow economy. Retrieved from: http://www.businessdictionary.com/definition/shadoweconomy.html

CITCO. IRS regulations - The Foreign Account Tax Compliance Act (FATCA) and its impact on the US foreign withholding tax and reporting system. Retrieved from: http://www.citco.com/sites/default/files/FATCA\%20general\%20facts\%20\%20October\%202011.pdf

Corruption Perception's Index. 2016. Retrieved from: http://www.transparency.org/news/feature/corruption_perceptions_index_2016

Duhaime's Law Dictionary. Definition of summary offence. Retrieved from: http://www.duhaime.org/LegalDictionary/S/SummaryConvictionOffence.aspx

Encyclopedia Britannica. Retrieved from: http://global.britannica.com/EBchecked/topic/584578/taxation

Foreman, A. (2015). Tax evasion's bite, from the ancient world to modern days. The Wall Street Journal. Retrieved from: http://www.wsj.com/articles/tax-evasions-bite-from-the-ancient-world-to-moidern-days-1443028212

Global Alliance for Tax Justice. Retrieved from: http://www.globaltaxjustice.org/about-us/

Gross, D.M. (2008). We won't pay: a tax resistance reader. CreateSpace Independent Publishing Platform. Retrieved from: https://books.google.co.za/books?id=pmLdrKqBcmYC\&pg=PR2\&lpg=PR2\&dq=David+M.+Gross, +ed. $+(2008) .+\mathrm{We}+$ Won\%E2\%80\%99t+Pay:+A+Tax+Resistance+Reader.\&source=bl\&ots=8A-j5eLDJZ\&sig=XUZvfiC8HR0YfZOYQacEer_fT8\&hl=en\&sa=X\&ved=0ahUKEwjU2sLzndPTAhVEOMAKHU4DjgQ6AEILTAD\#v=-onepage\&q=David\%20M.\%20Gross\%2C\%20ed.\%20(2008).\%20We\%20Won\%E2\%80\%99t\%2 0Pay\%3A\%20A\%20Tax\%20Resistance\%20Reader.\&f=false

HM Revenue \& Customs: Taxation. A tax to beat Napoleon. Retrieved from: www.hmrc.gov.uk/history/taxhis $1 . h t m$

HM Revenue \& Customs: Taxation. Retrieved from: http://webarchive.nationalarchives.gov.uk/+/http://www.hmrc.gov.uk/history/taxhis6.htm

HMIC. (2013). Her Majesty's revenue and customs disclosure compliance with criminal investigations. https://www.justiceinspectorates.gov.uk/hmic/media/hmrcs-disclosure-compliance-with-criminal-investigations20130610.pdf

HM Revenue and Customs. (2014). HMRC fast facts: Record revenues for the UK. May 2014 Bulletin. Retrieved from: https://www.gov.uk/government/uploads/system/uploads/attachment_data/file/326579/HMRC-fast-facts.pdf

Inland Revenue Division of Dominica. Taxation - It's nature and purpose. Retrieved from: http://ird.gov.dm/index.php?option=com_content\&view=article\&id=60:taxation-its-nature-and-purpose\&catid=25:present\&Itemid=27

IRS: Criminal investigation at-a-glance. Retrieved from: https://www.irs.gov/uac/criminal-investigation-ci-at-a-glance 
IRS: Foreign Account Tax Compliance Act. Retrieved from: https://www.irs.gov/businesses/corporations/foreign-account-taxcompliance-act-fatca

Kirchler, E. (2007). The economic psychology of tax behaviour. Cambridge: Cambridge University Press.

Kumarasingam, S. (2010). Tax avoidance and tax evasion explained and exemplified. Retrieved from: http://ezinearticles.com/?Tax-Avoidance-and-Tax-Evasion-Explained-and-Exemplified\&id=3590555

Law Teacher. The classification of criminal offences. http://www.lawteacher.net/law-help/lpc/criminal-litigation/classificationcriminal-offences.php

Lilley, P. (2012). Dirty Dealing: The untold truth about global money laundering, international crime and terrorism. Great Britain. Henry Ling Limited.

Messere K. C. and Owens, J. P. International comparisons of tax Levels: Pitfalls and insights. Retrieved from: https://www.oecd.org/eco/outlook/35589632.pdf

Ministry of Justice. (2015). Unlimited fines for serious offences. Retrieved from: https://www.gov.uk/government/news/unlimited-fines-for-serious-offences

Monti, M. Government quotes. Retrieved from: www.doublequotes.net/government_quotes/from-mario-monti

O’Brien, P. K. (2007). Atlas of World History. Oxford University Press. Retrieved from: https://books.google.co.za/books?id=ffZy5tDjaUkC\&pg=PA139\&lpg=PA139\&dq=china+qing+dynasty+war+against + tax + evasion\&source $=$ bl\&ots $=$ pb45Ape5f\&sig=2NNra7ecdD275qHPH3LKtoXBhgU\&hl=en\&sa=X\&ved=0ahUKEwjn7rvM_LrLAhUFWBoKHSyfAsMQ6 AEILDAE\# $\mathrm{v}=$ onepage $\& \mathrm{q}=$ china $\% 20 \mathrm{qing} \% 20$ dynasty $\% 20 \mathrm{war} \% 20$ against $\% 20 \mathrm{tax} \% 20 \mathrm{evasion} \& \mathrm{f}=$ false

Odom, W. (2015). Anatomy of a criminal tax case. Retrieved from: https://www.wendellodom.com/anatomy-of-a-criminal-taxcase-part-one/

Organization for Economic Co-operation and Development. (2014). Major new steps to boost international cooperation against tax evasion: Governments commit to implement automatic exchange of information beginning 2017. Retrieved from: http://www.oecd.org/newsroom/major-new-steps-to-boost-international-cooperation-against-tax-evasion-governmentscommit-to-implement-automatic-exchange-of-information-beginning-2017.htm

Oxford Dictionaries. Definition of shadow economy. Retrieved from: https://en.oxforddictionaries.com/definition/shadow_economy

Prosecuting Tax Evasion (2013). The Crown Prosecution Service. Retrieved from: http://www.cps.gov.uk/news/articles/prosecuting_tax_evasion/

Sansone v, US. (1965). United States Supreme Court: Sansone v. United States, (1965), No. 365. Retrieved from: http://caselaw.findlaw.com/us-supreme-court/380/343.html

SARS and the Criminal Justice System. The South African Revenue Service. Retrieved from: http://www.sars.gov.za/TargTaxCrime/WhatTaxCrime/Pages/SARS-and-the-Criminal-Justice-System.aspx

SARS. (2015). Huge successes in criminal convictions for tax crimes in 2014/15. Retrieved from: http://www.sars.gov.za/Media/MediaReleases/Pages/25\%20May\%202015\%20-

$\% 20$ Huge $\% 20$ successes $\% 20$ in $\% 20$ criminal $\% 20$ convictions $\% 20$ for $\% 20$ tax $\% 20$ crimes $\% 20 \mathrm{in} \% 202014 \% 20$ and $\% 202015$ .aspx

Schneider, F. (2013). Size and development of the shadow economies of Portugal and 35 other OECD Countries from 2003 to 2013: Some New Facts. Retrieved from: http://www.nipe.eeg.uminho.pt/Uploads/Seminarios\%202013/2013-0331_Schneider35otherOECD.pdf

SOI - Tax Stats. Internal Revenue Services. Retrieved from: https:/www.irs.gov/uac/SOI-Tax-Stats-Criminal-InvestigationProgram-by-Status-or-Disposition-IRS-Data-Book-Table-18

South Africa. (2011). Tax Administration Act No 28 of 2011. Retrieved from: http://www.lexisnexis.co.za/pdf/download-TaxAdminstration-Act.pdf

Swartley, W. M. (1980). The Christian and the Payment of Taxes Used for War. Retrieved from: http://peace.mennolink.org/articles/wartaxes.html

Tax Administration Act, 1953. Common Wealth Consolidated Acts see Australia.

Tax Administration Act No 28 of 2011 see South Africa.

Tax Crimes Explained. The Australian tax office. Retrieved from: https://www.ato.gov.au/general/the-fight-against-taxcrime/tax-crime-explained/

Tax Crime Prosecution Results. The Australian tax office. Retrieved from: https://www.ato.gov.au/General/the-fight-againsttax-crime/news-and-results/tax-crime-prosecution-results/

Tax Evasion Offences. Lexis PSL corporate crime. Retrieved from: https://www.lexisnexis.com/uk/lexispsl/corporatecrime/document/391421/55KB-9471-F188-N1BB-0000000/Tax\%20 evasion $\% 20$ offences $\%$ E2\%80\%94overview

Tax Fraud. Commonwealth Director of Public Prosecutions. Retrieved from: http://www.cdpp.gov.au/crimes-weprosecute/fraud/tax-fraud/

Taxation in South Africa 2014/2015. Retrieved from: http://www.sars.gov.za/AllDocs/OpsDocs/Guides/LAPD-Gen-G01\%20$\% 20$ Taxation $\% 20$ in $\% 20$ South $\% 20$ Africa $\% 20-\% 20$ External\%20Guide.pdf 
Taxation in South Africa 2014/2015. South African Revenue Service: Legal and Policy. Retrieved from: http://c.ymcdn.com/sites/sait.site-ym.com/resource/resmgr/2015_SARS_-_March/LAPD-Gen-G01_Taxation_in_S.pdf

Thackeray, F.W \& Finding, J.E. (2012). Events that formed the Modern World. ABC CLIO, LLC. Retrieved from: https://books.google.co.za/books?id=O2MhulpUa_cC\&pg=RA1-PA195\&lpg=RA1PA195\&dq $=$ china + qing + dynasty + war+against + tax + evasion\&source $=$ bl\&ots $=\mathrm{oQCCtbV9qu} \&$ sig $=\mathrm{jMGIAUJ}$ t84VSpUR

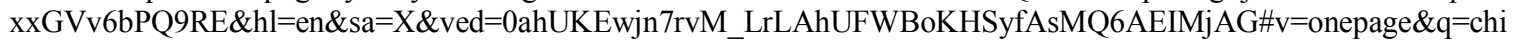
na\%20qing\%20dynasty\%20war\%20against $\% 20$ tax $\% 20$ evasion $\& \mathrm{f}=$ false

The Free Dictionary: Tax Resistance. Retrieved from: http://encyclopedia.thefreedictionary.com/Tax+resistance

Thesaurus. Definition of superannuation. Retrieved from: http://www.freethesaurus.com/superannuation

The Australian Tax Office. Retrieved from: https://www.ato.gov.au

The Tax Justice Network. The Cost of Tax Abuse: A briefing paper on the cost of tax evasion worldwide. 2011. Retrieved from: http://www.tackletaxhavens.com/Cost_of_Tax_Abuse_TJN_Research_23rd_Nov_2011.pdf

The World Factbook. Central Intelligence Agency. Retrieved from: $\bar{h}$ ttps://www.cia.gov/library/publications/the-worldfactbook/fields/2221.html

The Internal Revenue Code: Title 26 see United States of America.

The Organization for Economic and Co-operation Development. What we do and how. Retrieved from: http://www.oecd.org/about/whatwedoandhow/

The Organization for Economic and Co-operation Development. Major new steps to boost international cooperation against tax evasion: Governments commit to implement automatic exchange of information beginning 2017. Retrieved from: http://www.oecd.org/newsroom/major-new-steps-to-boost-international-cooperation-a...

The Tax Justice Network. Retrieved from: http://www.taxjustice.net/about/who-we-are/goals

The Taxes Management Act 1970 see United Kingdom.

The United States Code: Title 18 see United States of America.

United Kingdom. (1970). The Taxes Management Act. Retrieved from: http://www.legislation.gov.uk/ukpga/1970/9/contents/enacted

United States of America. The United States Code: Title 18. Retrieved from: https://www.law.cornell.edu/uscode/text/18

United States of America. The Internal Revenue Code: Title 26. Retrieved from: https://www.gpo.gov/fdsys/pkg/USCODE2011-title26/pdf/USCODE-2011-title26.pdf

US v Pomponio. (1976). United States Supreme Court: UNITED STATES v. POMPONIO, (1976), No. 75-1667. Retrieved from: http://caselaw.findlaw.com/us-supreme-court/429/10.html

US v Williams. (2001). Taxcrime! Obstructing the Due Administration of the Tax Code: The Orwellian Implications of 26 U.S.C. $\$ 7212(a)$. Retrieved from: http://www.swansonmcnamara.com/wp-content/uploads/2012/03/7212-Article.pdf

Venter, J. M. P, Stiglingh, M., Koekemoer, A. D., Oosthuizen, A., Cass, S. C. et al. (2015). Student approach to business activities. South Africa: LexisNexis. P. 517 - 537.

What is tax crime? Retrieved from: http://www.sars.gov.za/TargTaxCrime/WhatTaxCrime/Pages/default.aspx

World Bank. Retrieved from: http://data.worldbank.org

Your Dictionary. Definition of "felony". Retrieved from: http://www.yourdictionary.com/felony 


\section{NOTES}

